\title{
Study on the Utilization of Local Waste as a Construction Aggregates for the Production of Concrete Blocks
}

\author{
Hossam A. Elaqra ${ }^{1 *}$, Ajad M. Naim² and Mohammed K. Hussein² \\ ${ }^{1}$ Civil Engineering Department, University of Palestine (UP) \\ Gaza, Palestine \\ ${ }^{2}$ Civil Engineering Department, University College of Applied Sciences (UCAS) \\ Gaza, Palestine \\ ${ }^{*}$ Corresponding author's email: helaqra [AT] gmail.com
}

\begin{abstract}
This paper discusses the use of two different aggregates on the production of concrete blocks in construction. The use of aggregate type 1 showed a significant decrease on the compressive strength with 40\% replacement of natural aggregates. The use of aggregate type 2 , where the natural aggregate was totally replaced showed better results in term of compressive strength. At aggregate to cement ration equal to 4, the concrete has an acceptable density equal $1.4 \mathrm{~g} / \mathrm{cm}^{3}$ and compressive strength equal $2 \mathrm{MPa}$. The use of glass powder increases the compressive strength of these blocks to value higher than $3.5 \mathrm{MPa}$ and density around $1.3 \mathrm{~g} / \mathrm{cm}^{3}$ which is acceptable according to the ASTM for masonry block to be used in construction.
\end{abstract}

Keywords---- Light Weight Block Concrete, Light weight Aggregates, Bottom ash, Glass Powder, Compressive Strength

\section{INTRODUCTION}

The end of the last century has seen a revolution in construction towards the use of materials that respect the environment. The two terms "green cement and green building" became a new life mode.

The efficiently uses of the natural resources, the maximize use of local materials, the elimination of the waste; the efficient uses of energy systems are goals to be achieved in order to respect the environment.

The use of the incineration rest of biological waste as an alternative aggregate in construction as bricks can represent a solution for the accumulation waste.

In Gaza Strip, the bricks represent more than $75 \%$ of the total volume of construction materials. Therefore, this replacement represents a sustainable material, which respects the environment which can be the best choice on this field.

Since the Industrial Revolution, the world has witnessed incalculable technological achievements including population growth, and corresponding increases in resource use. Side effects were recognized like: pollution, landfills at capacity, toxic waste, global warming, resource and ozone depletion, and deforestation. These efforts are straining the limits of the Earth's "carrying capacity", its ability to provide the resources required to sustain life while retaining the capacity to regenerate and remain viable.

As the world's population continues to expand, implementation of resource-efficient measures in all areas of human activity is imperative. The built environment is one clear example of the impact of human activity on resources. Buildings have a significant impact on the environment.

The global concentration was given to establish Sustainable Built Environment as a new concept, which was invented to safeguard scares resources which became highly demanded, due to complicated modern developments which are dealing with extremely multifaceted modern technologies.

At the present time, the researches on bricks concern the construction for modern buildings, the bio-climatic architecture. In fact, one advantage of these bricks is that it has an interesting thermal and hygric properties [19], so that it can also be used for non-structural elements in modern buildings. In general, the use of waste materials is produced using very low consumption of energy and low emission of $\mathrm{CO}_{2}[20]$.

The Gaza Strip is suffering from the presence of huge quantities of waste with limited capacity to be recycled, which makes them accumulate and cause epidemics and diseases. These wastes include glass debris, olive press by product, as well as pottery by products (Bottom Ash), and other waste accumulated in landfills without any benefit.

The amount of solid waste in the Gaza Strip has been obtained and forecasted in different studies related to solid waste management in Gaza Strip. UNDP-APP (2012) study is one of the most recent studies, in which the present and the forecasted amounts of MSW for each governorate in the Gaza Strip were obtained based on the consultant own field assessments, interviews and celebrations [1]. The results are shown in table 1 below: 
Table 1: Forecasted waste generation per governorate in Gaza Strip (ton/day) [1]

\begin{tabular}{|l|l|l|l|l|l|}
\hline Year & North Gaza & Gaza & Khan Younis and & Rafah & Total \\
\hline $\mathbf{2 0 1 3}$ & 400 & 734 & 435 & 184 & 1753 \\
\hline $\mathbf{2 0 1 4}$ & 411 & 756 & 453 & 192 & 1813 \\
\hline $\mathbf{2 0 1 5}$ & 419 & 771 & 467 & 198 & 1855 \\
\hline $\mathbf{2 0 2 0}$ & 465 & 857 & 545 & 230 & 2097 \\
\hline $\mathbf{2 0 2 5}$ & 500 & 922 & 672 & 281 & 2375 \\
\hline $\mathbf{2 0 3 0}$ & 531 & 979 & 819 & 339 & 2668 \\
\hline $\mathbf{2 0 3 5}$ & 564 & 1040 & 912 & 361 & 2877 \\
\hline $\mathbf{2 0 4 0}$ & 593 & 1092 & 958 & 380 & 3023 \\
\hline
\end{tabular}

Solid waste includes all types of waste produced by various domestic solid wastes, commercial waste, industrial and agricultural wastes, construction and demolition waste. Household solid waste is the residue of household waste, whether it is meat, vegetables, fruit or grains. It also includes paper, glass, beverage cans, etc..... The sources of commercial wastes are stored, commercial malls, markets and organization of the governmental and private companies. [3]

There is a difference between the quantity and composition of waste from one country to another and from a residential area to another one, where there is a close correlation between the quality and quantity of waste with the population and income per capita in the Gaza Strip. The average MSW composition (\% by weight) contains $67.0 \%$ organic matter, $8 \%$ Paper, $2 \%$ textiles, $7 \%$ plastics, $2 \%$ glass, $2 \%$ metals, $10 \%$ sand and $2 \%$ [3].

As the amount of replacement of natural aggregates by bottom ash shows a decrease in the workability and the need to increase water to cement ratio to achieve a suitable workability, which comes from the higher water absorption of the bottom ash [2, 8, 10, 11, 15-17].

The replacement of sand by $30 \%$ of bottom ash shows lower density and accepted compressive strength to be used as concrete block [4].

Other research shows a decrease of $95 \%$ of compressive strength with the replacement of sand by $40 \%$ of bottom ash and $4 \%$ lower in density which is not suitable to be sued as concrete block [5].

The replacement of fine aggregates by bottom ash and the use of silica fume shows an increase of the compressive strength, the $30 \%$ replacement shows the same compressive strength as the reference [6].

The replacement of $20 \%$ of bottom ash shows the optimum that will be used of $40 \%$ mix decreases the compressive strength up to $16 \%$ [7].

The use of $30 \%$ of washed bottom ash shows an optimum to be used as concrete with suitable compressive strength [2 and 9].

The use of $25 \%$ of bottom ash as sand replacement shows a decrease of $20 \%$ of the compressive strength and $1 \%$ of the density [12].

While the use of $20 \%$ of bottom ash as sand replacement shows acceptable compressive strength [13 and 14]. Other shows that the use of $15 \%$ is the optimum to be used [3].

The use of steam curing has a positive effect on the compressive strength of concrete up to $50 \%$ replacement of fine aggregates by bottom ash [17].

Table 2 shows a summary of previous research on the optimum amount of BA which gives the higher compressive strength.

Table 1: Summary of previous research on fine aggregates replacement by BA.

\begin{tabular}{|c|c|c|}
\hline Ref & Bttom ahs size & Optimum \\
\hline $\mathbf{2}$ & $0-4.75 \mathrm{~mm}$ & $30 \%$ \\
\hline $\mathbf{3}$ & $0-4.75 \mathrm{~mm}$ & $15 \%$ \\
\hline $\mathbf{4}$ & $0-4.75 \mathrm{~mm}$ & $30 \%$ \\
\hline $\mathbf{5}$ & $0-4.75 \mathrm{~mm}$ & $20 \%$ \\
\hline $\mathbf{7}$ & $0-4.75 \mathrm{~mm}$ & $5 \%$ \\
\hline $\mathbf{8}$ & $0-4.75 \mathrm{~mm}$ & $10 \%$ \\
\hline $\mathbf{1 1}$ & $0-4.75 \mathrm{~mm}$ & $30 \%$ \\
\hline $\mathbf{1 3}$ & $0-4.75 \mathrm{~mm}$ & $25 \%$ \\
\hline $\mathbf{1 4}$ & $0-4.75 \mathrm{~mm}$ & $20 \%$ \\
\hline
\end{tabular}

This paper discusses the possibility of the total replacement of natural aggregates by bottom ash comes from the rest of the incineration of biological waste (rest of pressing olive and poetry industry) on concrete blocks with lower density and suitable compressive strength. By the use of concrete bricks with lower density more than one goal can be achieved:

1- The respect of the environment by the reuse of waste in useful ways. 
2- The reduction of the dead load of the construction material and as a result we have less steel and concrete.

3- Obtained concrete block with interesting thermal and hygric properties.

\subsection{Materials}

\section{EXPERIMENTAL AND TESTING PROGRAM}

Ingredients of the concrete mixes are described in details with their properties as follow:

\subsubsection{Cement and Glass Powder}

Nesher CEMII AMSVL 42.5 is used in this study. Local glass sheets and broken pieces collected from landfill, crushed and milled glass waste into particles size less than $75 \mu \mathrm{m}$. Table 2 shows the chemical composition of cement and glass powder (GP) as determined by XRF measurements according to ASTM D5357-03 [21].

Table 2: Chemical composition of the cement and the glass powder (GP) [23].

\begin{tabular}{|l|c|c|c|c|c|c|c|c|c|}
\hline & $\begin{array}{c}\mathrm{CaO} \\
(\%)\end{array}$ & $\begin{array}{c}\mathrm{SiO}_{2} \\
(\%)\end{array}$ & $\begin{array}{c}\mathbf{A l}_{2} \mathbf{O}_{3} \\
(\%)\end{array}$ & $\begin{array}{c}\mathbf{F e}_{2} \mathbf{O}_{3} \\
(\%)\end{array}$ & $\begin{array}{c}\mathbf{S O}_{3} \\
(\%)\end{array}$ & $\begin{array}{c}\mathbf{P}_{2} \mathbf{O}_{5} \\
(\%)\end{array}$ & $\begin{array}{c}\mathbf{M g O} \\
(\%)\end{array}$ & $\begin{array}{c}\mathrm{KO}_{2} \\
(\%)\end{array}$ & $\begin{array}{c}\mathbf{N a}_{2} \mathrm{O}^{(\%)} \\
(\%)\end{array}$ \\
\hline CEMII & 66.69 & 18.84 & 6.3 & 3.72 & 2.66 & 0.70 & 0.61 & 0.5 & 0 \\
\hline GP & 18.55 & 64.94 & 1.81 & 1.97 & 0 & 0 & 3.12 & 0.44 & 9.16 \\
\hline
\end{tabular}

Fig. 1 shows the particle size distribution (PSD) of the cement (CEM II) and the Glass Powder (GP) according to ASTM C136 / C136M-14 [2 2 ]. The figure shows that CEMII has finer particle size than GP [18].

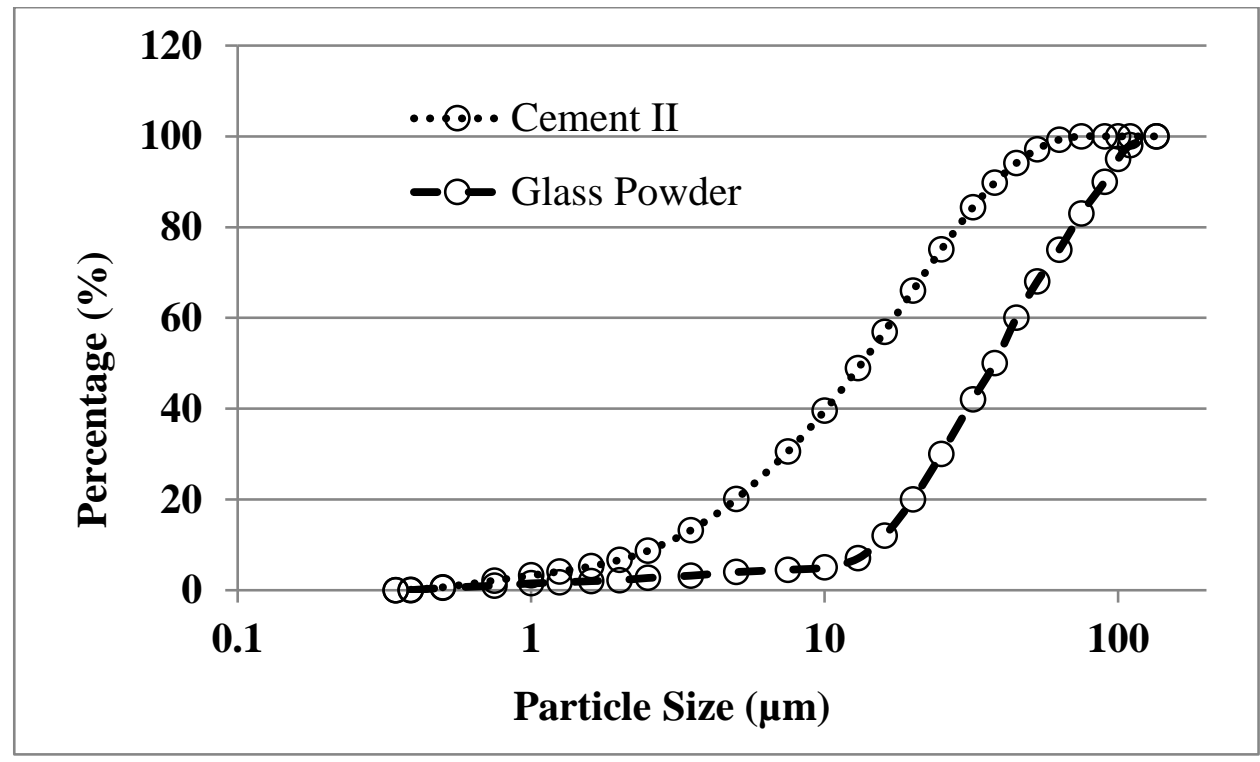

Fig. 1: Particle size distribution of CEM II and glass powder [18].

\subsubsection{Aggregates}

Two types of aggregate were used, aggregate A (Jeft) which comes from the incineration of the rest of olive after pressing) and aggregate B (Fawakher) which comes from the rest of incineration of wood and other ingredient in the poetry industry. Sieve analyses of aggregates were obtained according to ASTM (C136) [22] and the sieves used were the standard U.S. sieves. Fig. 2 shows the particle size distribution for Jeft and Fawakher aggregates. Both aggregates have the size of fine aggregate in the range between 0 and $4.75 \mathrm{~mm}$, The Jeft aggregates shows more fine particles than the Fawakher aggregates do. 


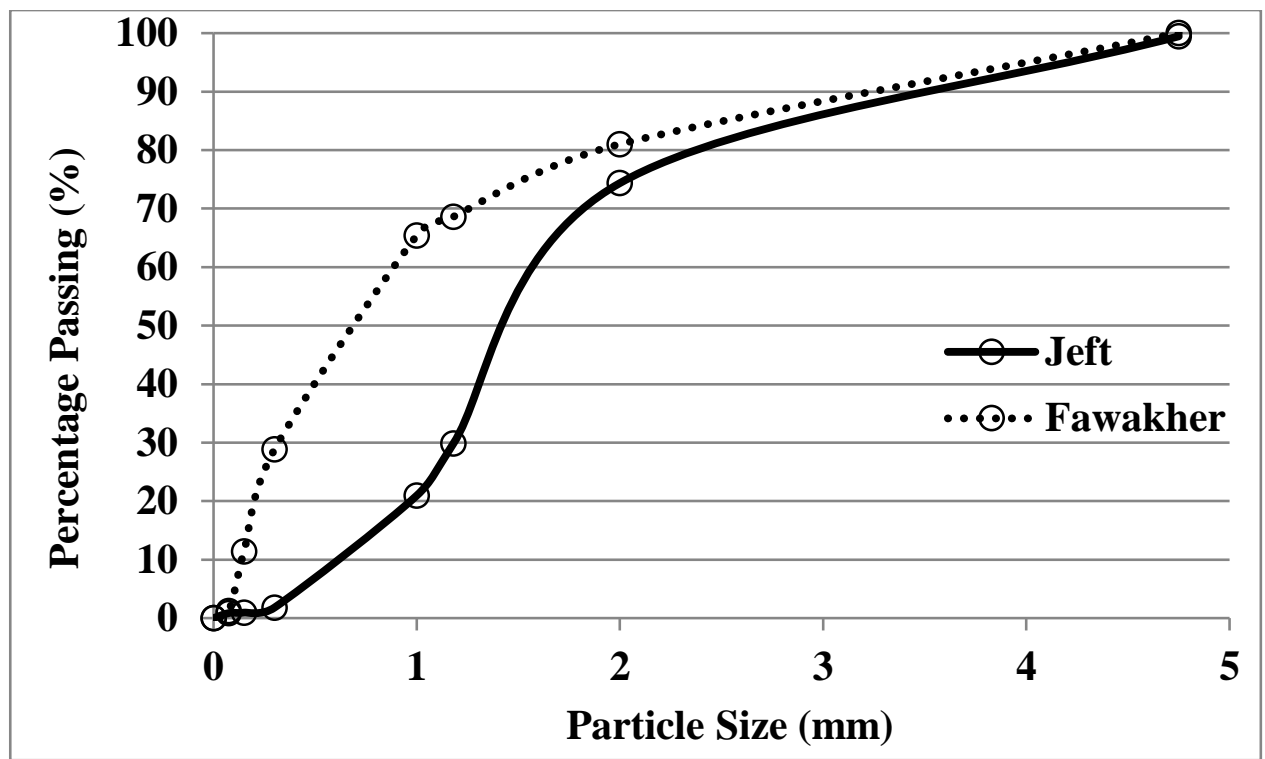

Fig. 2: Particle Size Distribution of Jeft and Fawakher aggregates.

\subsection{Mix Proportions and Mix Design}

\subsubsection{Concrete}

The cement and aggregates were mixed dry for two minutes according to ASTM C192 / C192M-16a [23]. The water is to be added to the cement and aggregates and mix slowly for over 2 minutes and the whole ingredients were mixed in a mixer which stops for 4 minutes. The last step of mixing was done for 2 minutes. 10x10x10 cm concrete cubes were cast for the compressive strength test according to ASTM C39 / C39M-18 [25]. The samples were kept at 100\% humidity for 24 hours then demoded, weighted and cured in water at room temperature for 2, 7 and 28 days.

In order to investigate the effect of the GP particles on the density and the compressive strength, the GP is immersed in water for $3 \mathrm{Hs}$ before mixing with the wet aggregates. The aim of the immersion is to dissolve the GP particles in the water into free ions $\mathrm{SiO}_{2}, \mathrm{CaO}$ and $\mathrm{Na}_{2} \mathrm{O}$ [3]. This leads to forming more $\mathrm{CSH}$ than $\mathrm{CH}$ which is stronger in compressive strength and higher in density.

Table 3: Mix proportions of concrete made with Jeft as a replacement of sand and fine aggregates with w/c $=0.8$ for $1 \mathrm{M}^{3}$.

\begin{tabular}{|l|l|l|l|l|l|l|}
\hline Mix & $\begin{array}{l}\text { Cement } \\
\text { Kg }\end{array}$ & $\begin{array}{l}\text { Sand } \\
\text { Kg }\end{array}$ & $\begin{array}{l}\text { Fine aggreagte } \\
\text { Kg }\end{array}$ & $\begin{array}{l}\text { Jeft } \\
\text { Kg }\end{array}$ & $\begin{array}{l}\text { Water } \\
\text { Kg }\end{array}$ & W/C \\
\hline $\mathbf{0 \%}$ & 315 & 74 & 1854 & 0 & 252 & 0.8 \\
\hline $\mathbf{5 0 \%}$ & 315 & 37 & 928 & 965 & 252 & 0.8 \\
\hline $\mathbf{7 5 \%}$ & 315 & 19 & 464 & 1447 & 252 & 0.8 \\
\hline $\mathbf{1 0 0 \%}$ & 315 & 0 & 0 & 1930 & 252 & 0.8 \\
\hline
\end{tabular}

Table 4: Mix proportions of concrete made with Jeft and BA as a replacement of sand and fine aggregates with adjusted $\mathrm{w} / \mathrm{c}$ ratio in order to obtain a workable concrete for $1 \mathrm{M}^{3}$.

\begin{tabular}{|l|l|l|l|l|l|}
\hline Mix & $\begin{array}{l}\text { Cement } \\
\text { Kg }\end{array}$ & $\begin{array}{l}\text { Sand } \\
\text { Kg }\end{array}$ & $\begin{array}{l}\text { Fine aggregate } \\
\text { Kg }\end{array}$ & $\begin{array}{l}\text { Jeft } \\
\text { Kg }\end{array}$ & $\begin{array}{l}\text { Bottom Ash } \\
\text { Kg }\end{array}$ \\
\hline $\mathbf{0 \%}$ & 600 & 800 & 2500 & 0 & 0 \\
\hline $\mathbf{2 0 \%}$ & 600 & 160 & 500 & 260 & 400 \\
\hline $\mathbf{3 0 \%}$ & 600 & 240 & 750 & 390 & 600 \\
\hline $\mathbf{4 0 \%}$ & 600 & 320 & 1000 & 520 & 800 \\
\hline
\end{tabular}


Table 5: Mix proportions of concrete made with Fawaker (rest of incineration of wood in poetry industry) with an adjusted w/c ratio in order to obtain a workable concrete for $1 \mathrm{M}^{3}$.

\begin{tabular}{|l|l|l|l|c|}
\hline Mix & $\begin{array}{l}\text { Cement } \\
\text { Kg }\end{array}$ & $\begin{array}{l}\text { Fawakher } \\
\text { Kg }\end{array}$ & $\begin{array}{l}\text { Water } \\
\text { Kg }\end{array}$ & Water/cement \\
\hline $\mathbf{0 . 5}$ & 600 & 300 & 312 & 0.52 \\
\hline $\mathbf{1}$ & 600 & 600 & 324 & 0.54 \\
\hline $\mathbf{1 . 5}$ & 600 & 900 & 444 & 0.74 \\
\hline $\mathbf{2}$ & 600 & 1200 & 495 & 0.99 \\
\hline $\mathbf{2 . 5}$ & 600 & 1500 & 750 & 1.25 \\
\hline $\mathbf{3}$ & 600 & 1800 & 714 & 1.19 \\
\hline $\mathbf{3 . 5}$ & 600 & 2100 & 840 & 1.4 \\
\hline $\mathbf{4}$ & 600 & 2400 & 1014 & 1.69 \\
\hline
\end{tabular}

Table 6: Mix proportions of concrete made with Fawakher, BA and Glass Powder (GP) as the cement replacement with $\mathrm{w} / \mathrm{c}=1.4$ for $1 \mathrm{M}^{3}$.

\begin{tabular}{|c|c|c|c|c|c|}
\hline Mix & $\begin{array}{l}\text { Cement } \\
\mathrm{Kg}\end{array}$ & $\begin{array}{l}\text { Fawakher } \\
\text { Kg }\end{array}$ & $\begin{array}{l}\text { GP } \\
\text { Kg }\end{array}$ & $\begin{array}{l}\text { Water } \\
\mathrm{Kg}\end{array}$ & Water /cement \\
\hline $0 \%$ & 600 & 2100 & 840 & 0 & 1.4 \\
\hline $5 \%$ & 570 & 2100 & 840 & 30 & 1.4 \\
\hline $10 \%$ & 540 & 2100 & 840 & 60 & 1.4 \\
\hline $20 \%$ & 480 & 2100 & 840 & 120 & 1.4 \\
\hline $30 \%$ & 570 & 2100 & 840 & 180 & 1.4 \\
\hline
\end{tabular}

\subsection{Test Procedure}

\subsection{1: Density}

The density was calculated directly by dividing the mass of concrete sample by its volume $\left(\rho=\frac{M}{V}\right)$, according to ASTM C642-13 [29].

\subsection{Mechanical Testing}

\subsubsection{Compressive Strength Tests}

The compression tests were conducted according to ASTM C39 / C39M-18 [30] at the age of 2, 7, and 28 days using $10 * 10 * 10 \mathrm{~cm}$ cubes. Three samples were tested for each mix and the average was reported in the results. Fig. 3 shows the concrete sample after being crushed.

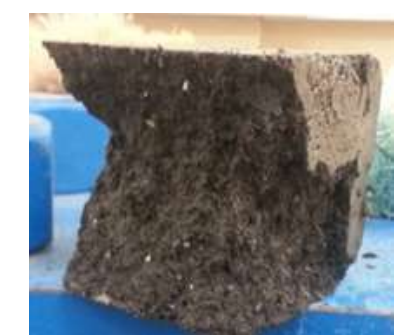

Fig. 3: Concrete sample after crushed.

\subsection{Fresh concrete properties}

\section{RESULTS}

\subsubsection{Density}

Fig. 4 shows the density of concrete as a function of age and replacement of natural aggregates by Jeft aggregates. The results show a decrease of the density with the replacement and an increase with the age. The lowest density is obtained at $100 \%$ mix which is around $1.5 \mathrm{~g} / \mathrm{cm}^{3}$ at 28 days. 


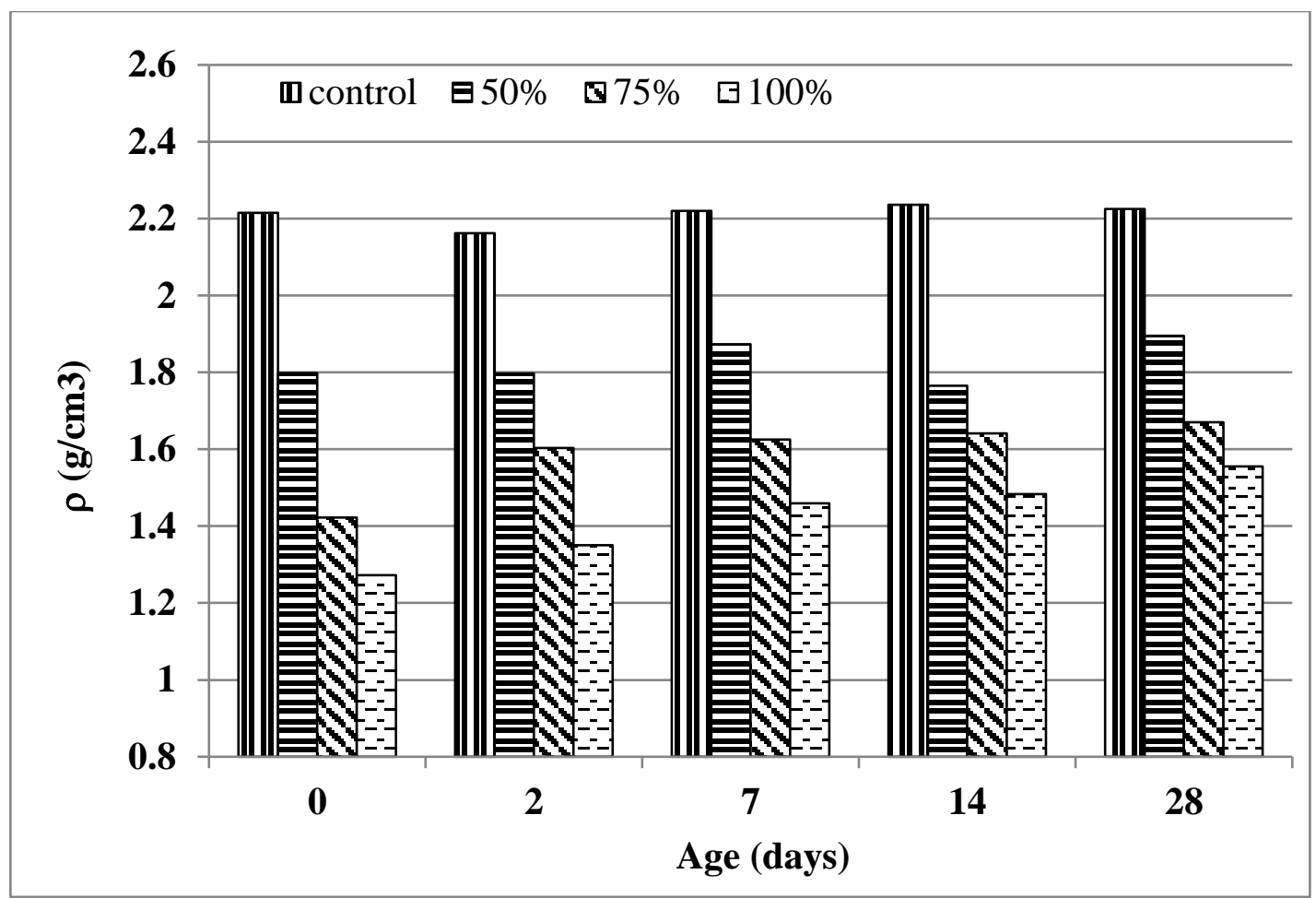

Fig. 4: Density of concrete as a function of age and replacement of natural aggregate by Jeft aggregates.

Fig. 5 shows the density as a function of age and replacement of natural aggregates by Jeft and BA. The results show a decrease of the density with the replacement and a decrease with the age. The lowest density is obtained at $40 \%$ mix which is around $1.4 \mathrm{~g} / \mathrm{cm}^{3}$ at 28 days.

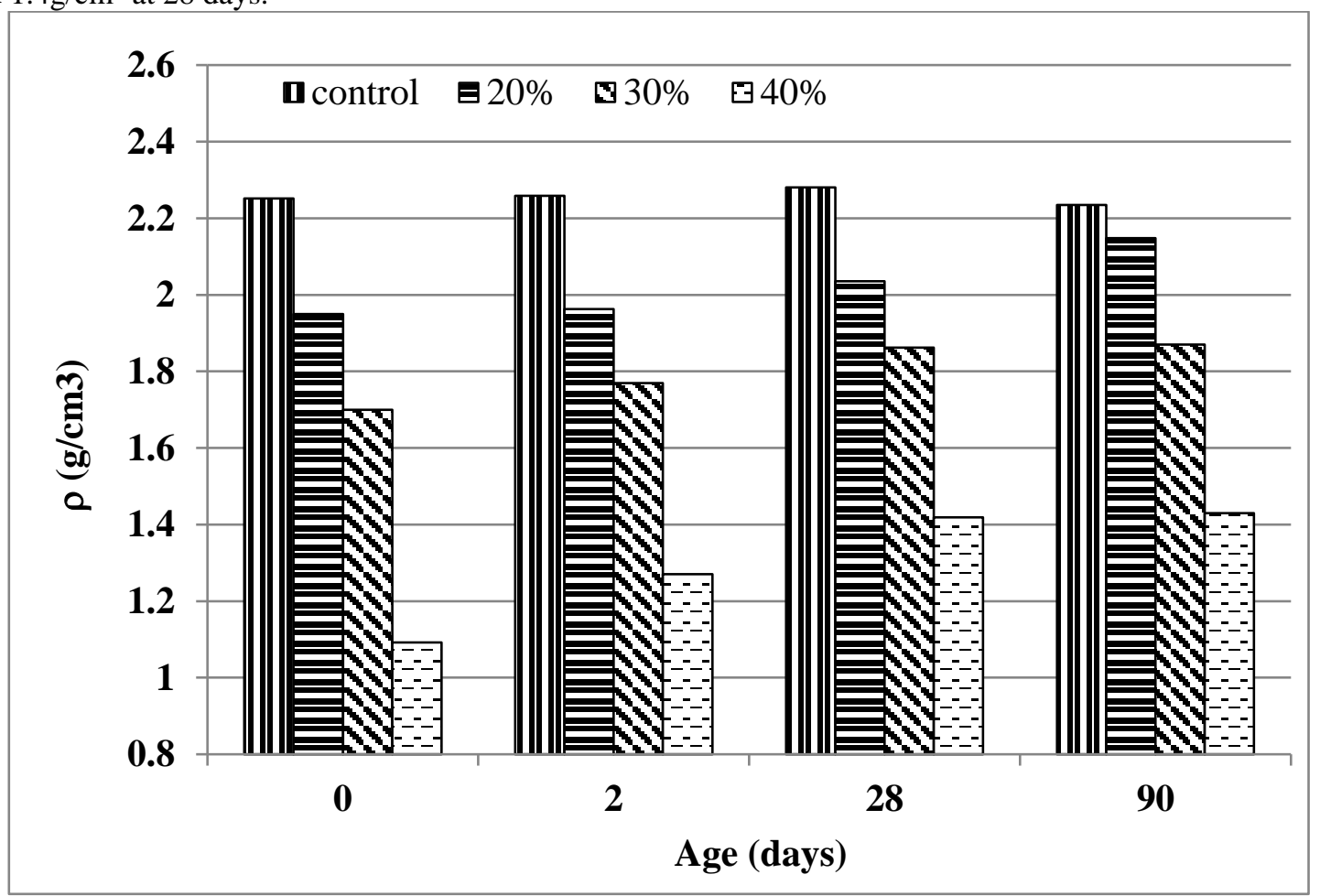

Fig. 5: Density of concrete as a function of age and replacement of natural aggregate by Jeft and BA aggregates.

Fig. 6 shows the density of concrete as a function of age and the amount of Fawakher to cement from0.5 to 4 . The lowest density is obtained at Fawakher to cement $=4$, which is around $1.4 \mathrm{~g} / \mathrm{cm}^{3}$ at 28 days. 


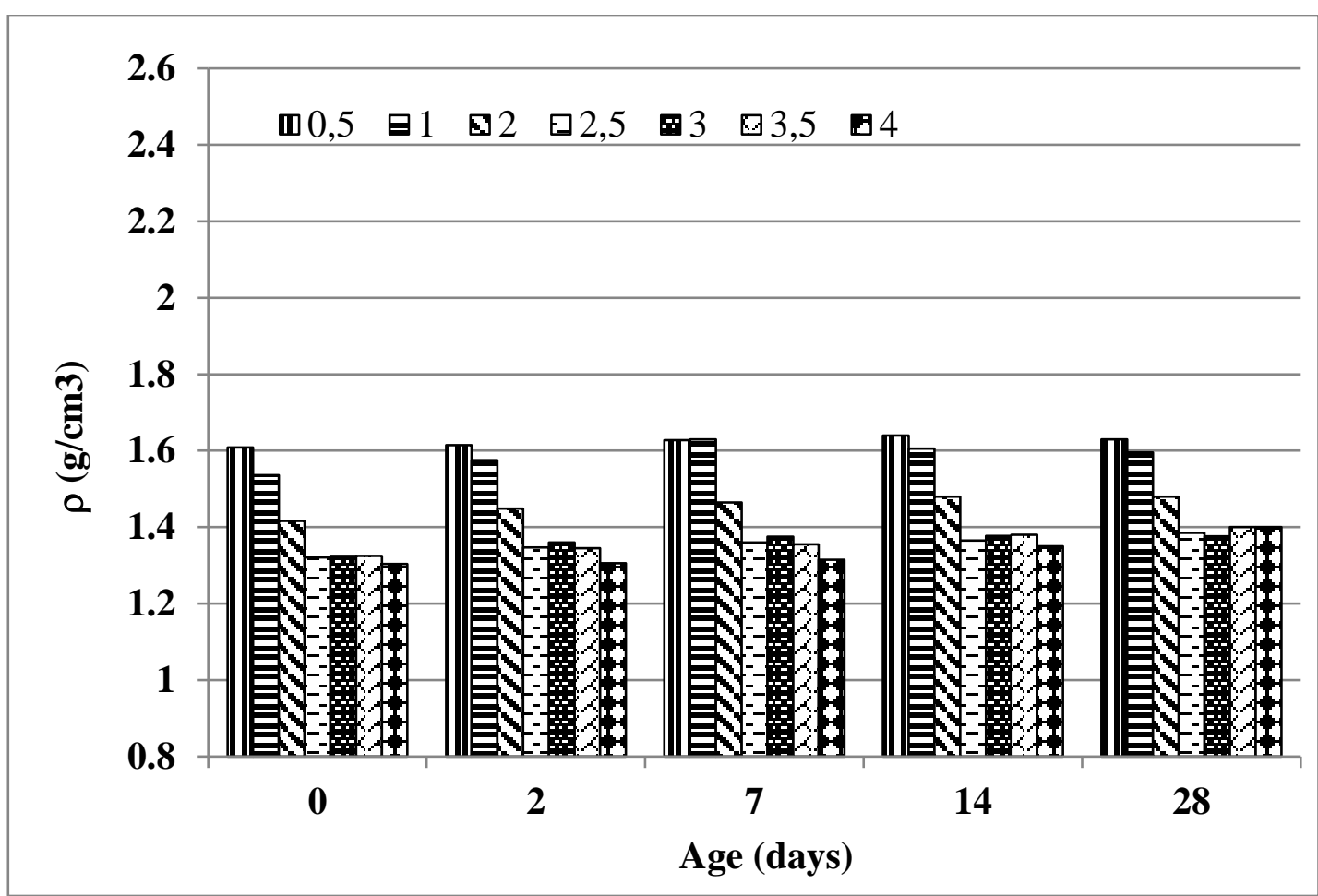

Fig. 6: Density of concrete as a function of age and replacement of natural aggregate by Fawakher aggregates.

Fig. 7 shows the density as a function of age and cement replacement by GP. The results show an increase with the replacement and the age. The highest density is obtained at $30 \%$ GP mix which is around $1.4 \mathrm{~g} / \mathrm{cm}^{3}$ at 28 days.

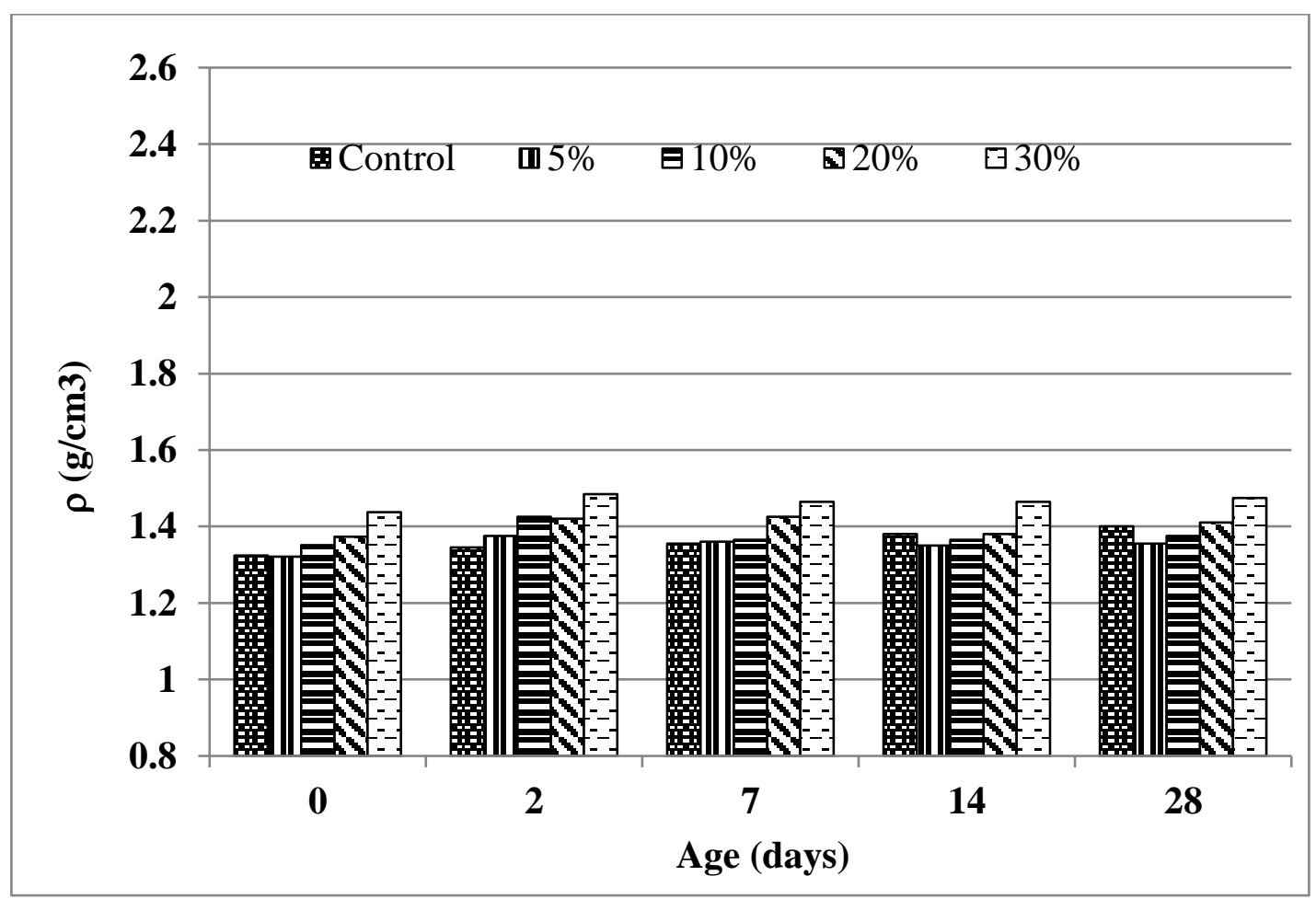

Fig. 7: Density of concrete as a function of age and replacement of cement by GP.

\subsection{Hardened Properties}

\subsubsection{Mechanical Properties}

The mechanical properties were obtained for the concrete prepared by the conventional mixing method and the new mixing method. 


\subsubsection{Compressive Strength Tests}

Fig. 8 shows the compressive strength as a function of age and replacement of natural aggregate by Jeft aggregates. The results show an increase of the compressive strength with the age and a decrease with the replacement. The lowest compressive strength is obtained at $100 \%$ mix, which is around $2 \mathrm{MPa}$.

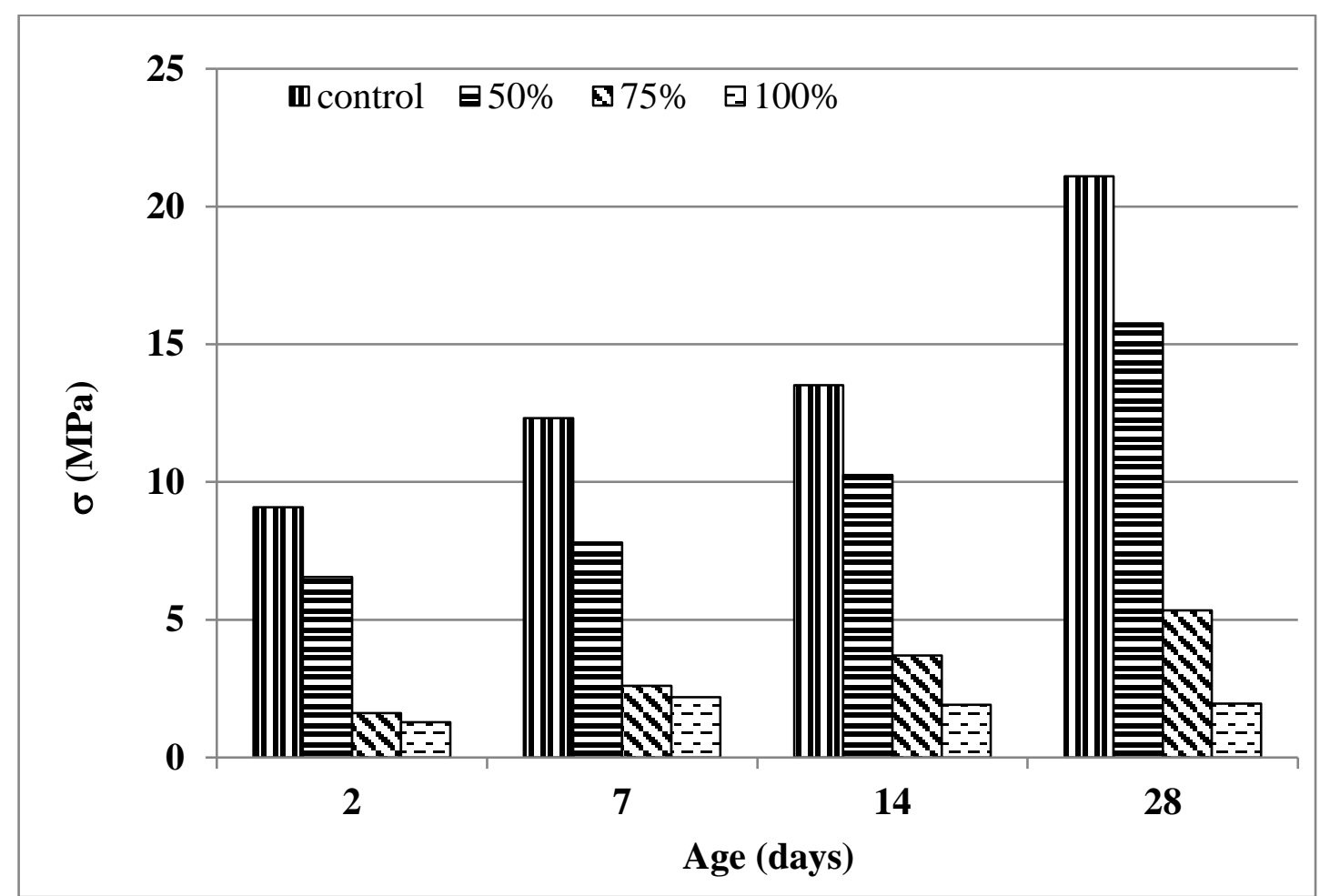

Fig. 8: Compressive strength of concrete as a function of age and replacement of natural aggregate by Jeft aggreagtes.

Fig. 9 shows the compressive strength as a function of age and replacement of natural aggregate by Jeft and BA aggregates. The results show an increase of the compressive strength with the age and a decrease with the replacement. The lowest compressive strength is obtained at $40 \%$ mix, which is less than $0.5 \mathrm{MPa}$. 


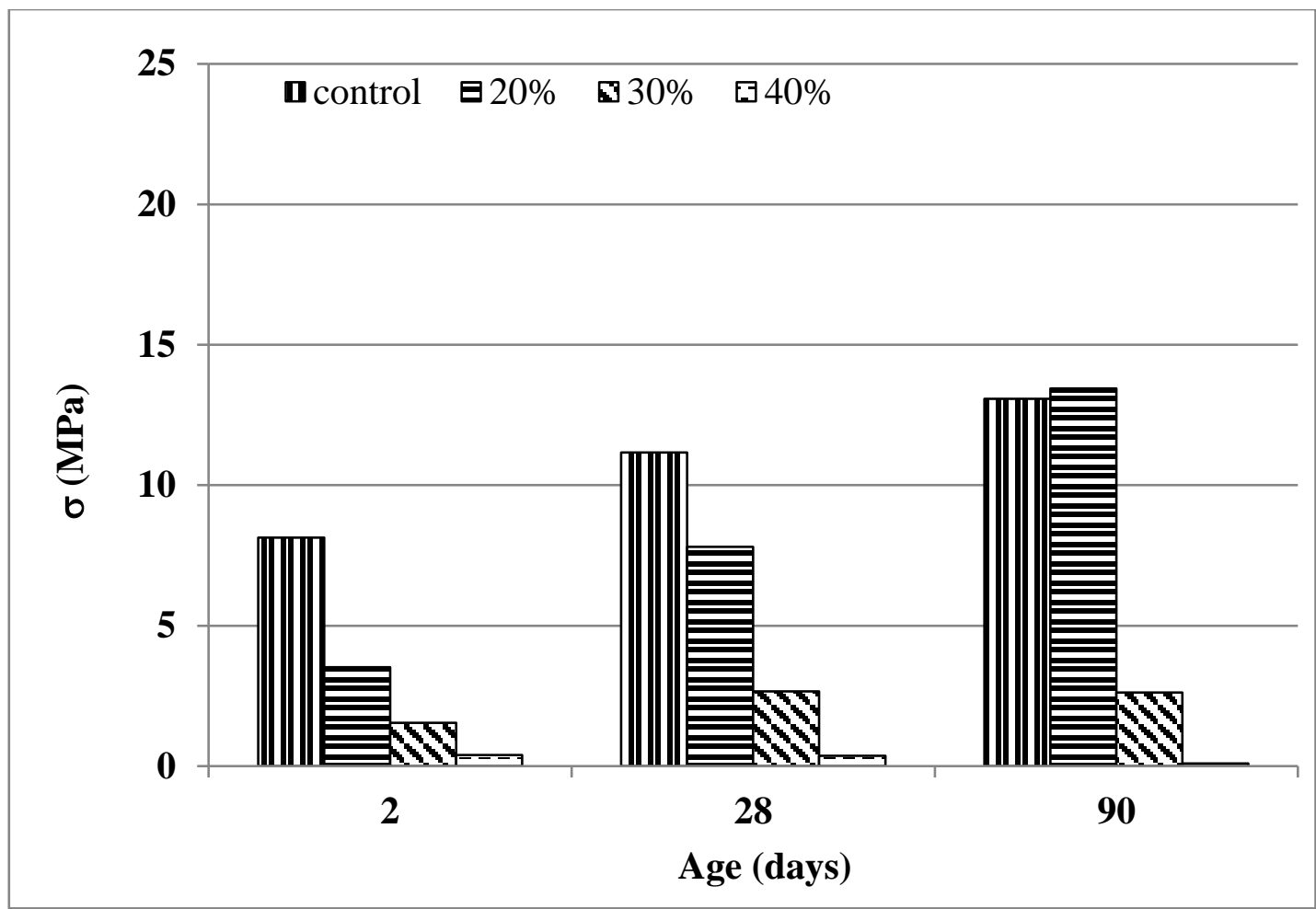

Fig. 9: Compressive strength of concrete as a function of age and replacement of natural aggregate by Jeft and BA aggreagtes.

Fig. 10 shows the compressive strength as a function of age and Fawakher to cement ratio. The results show an increase of the compressive strength with the age and a decrease with the replacement. The lowest compressive strength is obtained at $40 \%$ mix, which is around $2 \mathrm{MPa}$.

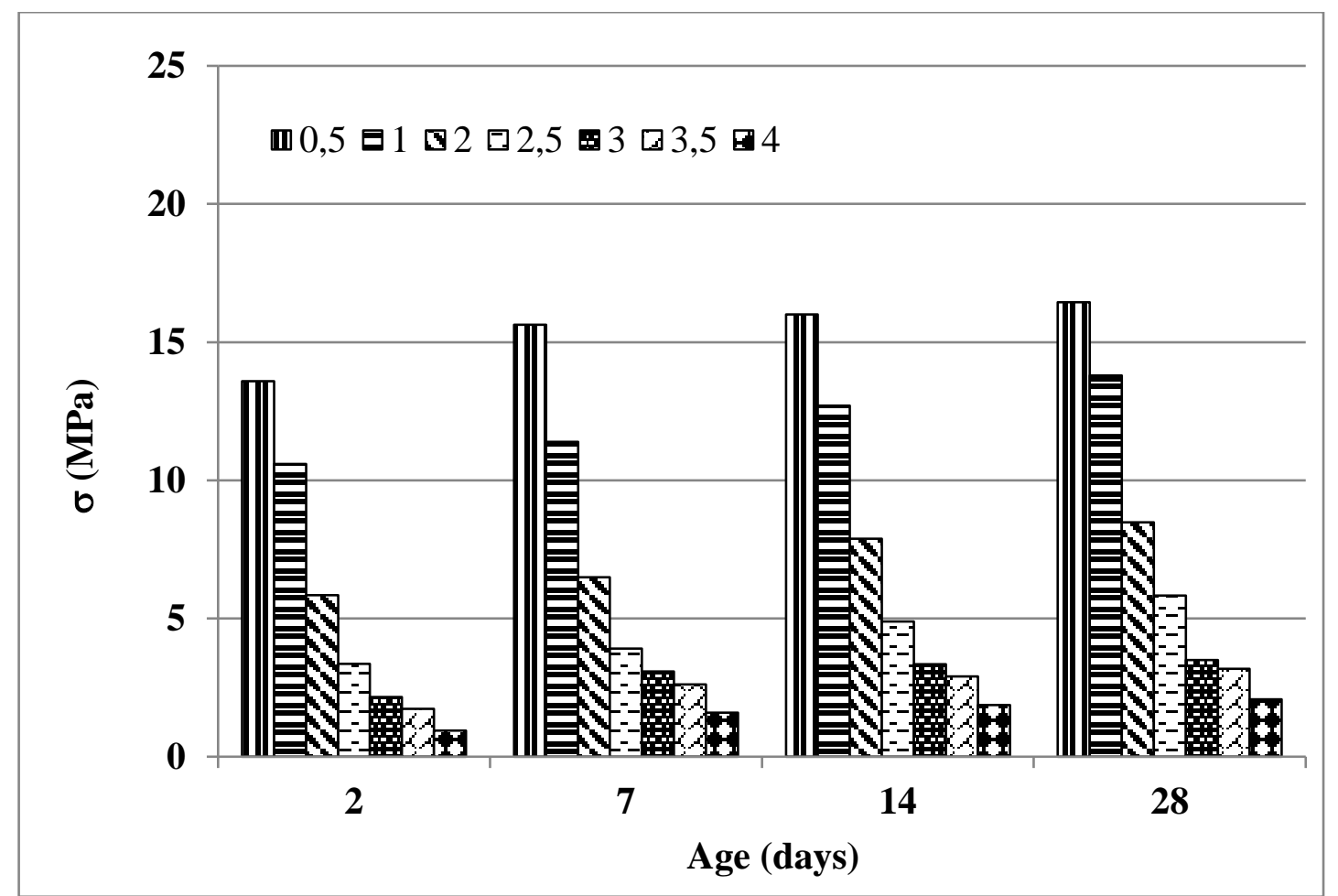

Fig. 10: Compressive strength of concrete as a function of age and replacement of natural aggregate by Fawakher aggregates.

Fig. 11 shows the compressive strength as a function of age and cement replacement with GP. The results show an increase 
of the compressive strength with the age and the GP replacement. The highest value is obtained at $30 \%$ mix which is around $4 \mathrm{MPa}$.

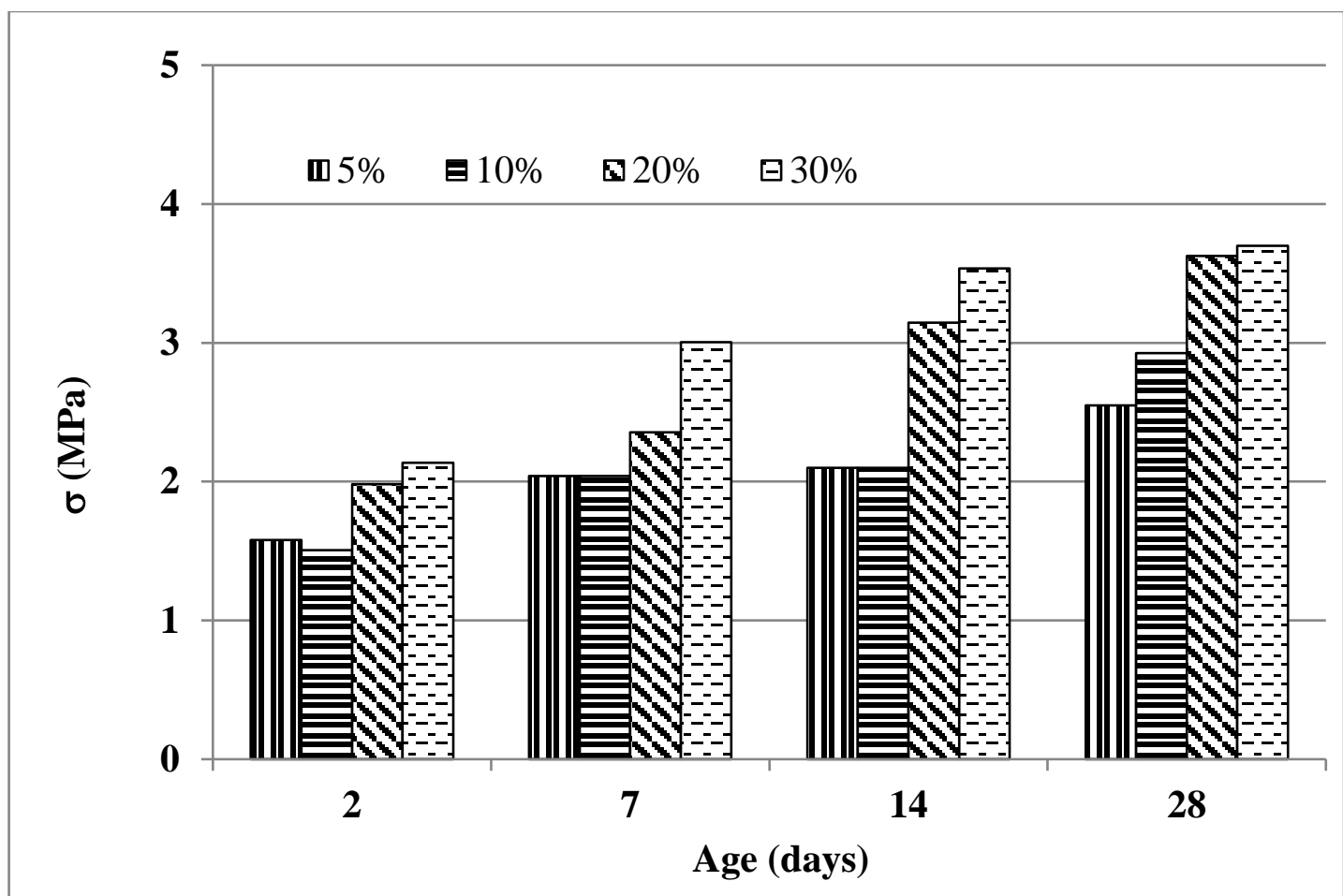

Fig. 11: Compressive strength of concrete as a function of age and replacement of cement by GP.

\section{DISCUSSION}

The replacement of natural aggregates by Jeft decreases the density which comes from the lower density of Jeft than the natural aggregates. The replacement by Jeft and BA decreases the density at a lower amount than for the Jeft replacement which comes from the higher water to cement ratio.

The increase of fawakher to cement ratio decreases the density due to the lower density of fawkher aggregates. The increase of the GP replacement leads to an increase in the density, it supposes that the immersion of GP particles in the water leads to having more free ions $\mathrm{SiO}_{2}, \mathrm{CaO}$ and $\mathrm{Na}_{2} \mathrm{O}$ and higher density by the conversion of $\mathrm{CH}$ to CSH [23, 32-33].

The replacement of natural aggregates by Jeft decreases the compressive strength which comes from the weaker Jeft aggregates than the natural aggregates. The replacement by Jeft and BA decreases the compressive strength at lower amount than for the Jeft replacement which comes from the higher water to cement ratio.

The increase of fawakher to cement ratio decreases the compressive strength due to the weaker fawkher aggregates. The increase of the GP replacement leads to an increase in the compressive strength, it supposes that the immersion of GP particles in the water leads to having more free ions $\mathrm{SiO}_{2}, \mathrm{CaO}$ and $\mathrm{Na}_{2} \mathrm{O}$ and higher compressive strength by the conversion of $\mathrm{CH}$ to $\mathrm{CSH}[18,26-28]$.

\section{CONCLUSION}

Fig. 12 shows the compressive strength as a function of the density of all mixes. Two groups were obtained; group A represents mixes with higher density (more than $2 \mathrm{~g} / \mathrm{cm}^{3}$ ) and higher compressive strength (more than $15 \mathrm{MPa}$ ). While group $\mathrm{B}$, represents mixes with lower density (less than $2 \mathrm{~g} / \mathrm{cm}^{3}$ ) and lower compressive strength (lower than $5 \mathrm{MPa}$ ) which can be used as concrete blocks. 


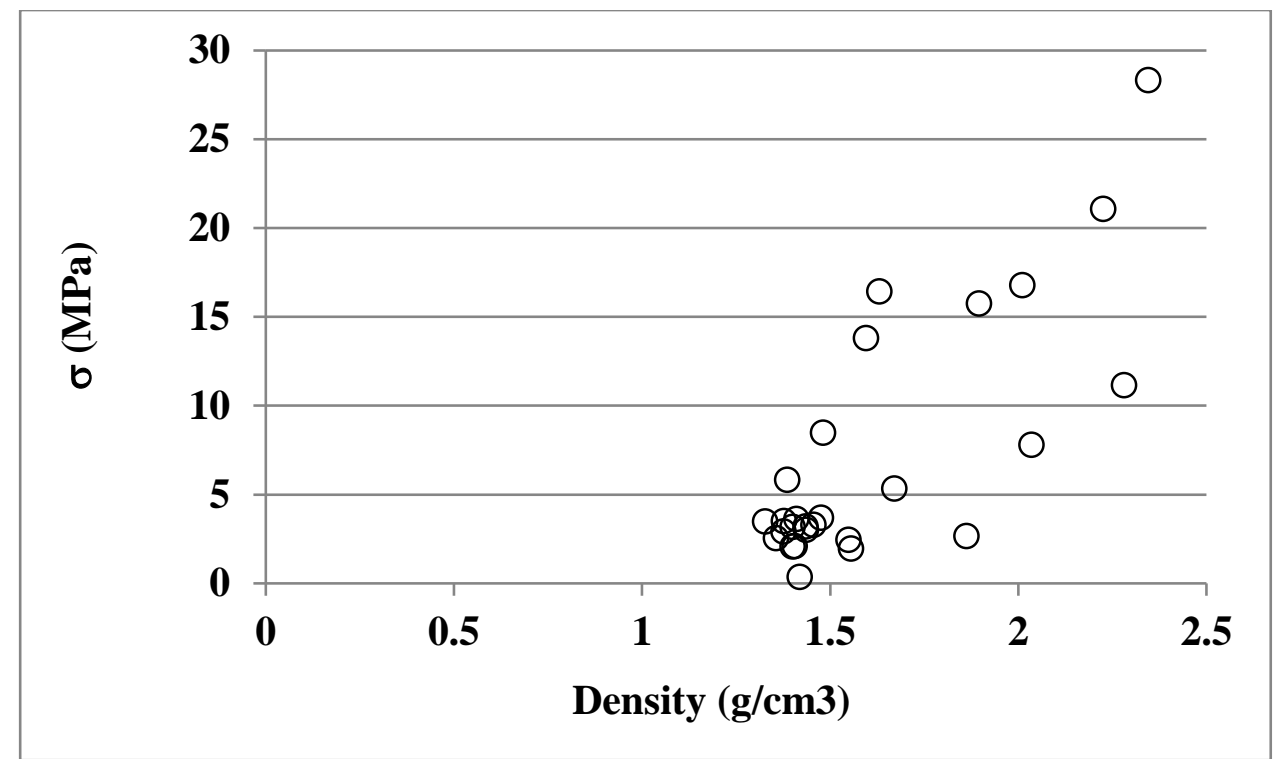

Fig. 12: Compressive strength as a function of density for all mixes.

Fig. 13 represents the compressive strength as a function of the density of mixes with lower density. The mixes with lower density around $1.4 \mathrm{~g} / \mathrm{cm}^{3}$ and compressive strength around $3 \mathrm{MPa}$ are suitable to be used as concrete blocks. On other hand the use of hot curing around $100^{\circ} \mathrm{C}$ leads to having mixes with lower density (from $1.4 \mathrm{~g} / \mathrm{cm}^{3}$ to $1.1 \mathrm{~g} / \mathrm{cm}^{3}$ ) and higher compressive strength (from $3 \mathrm{MPa}$ to $5 \mathrm{MPa}$ ). These results can be the second step on this research and the use of other binders, like the lime, can lead to a higher compressive strength with the use of steam or heat curing, this was confirmed by other researcher [26].

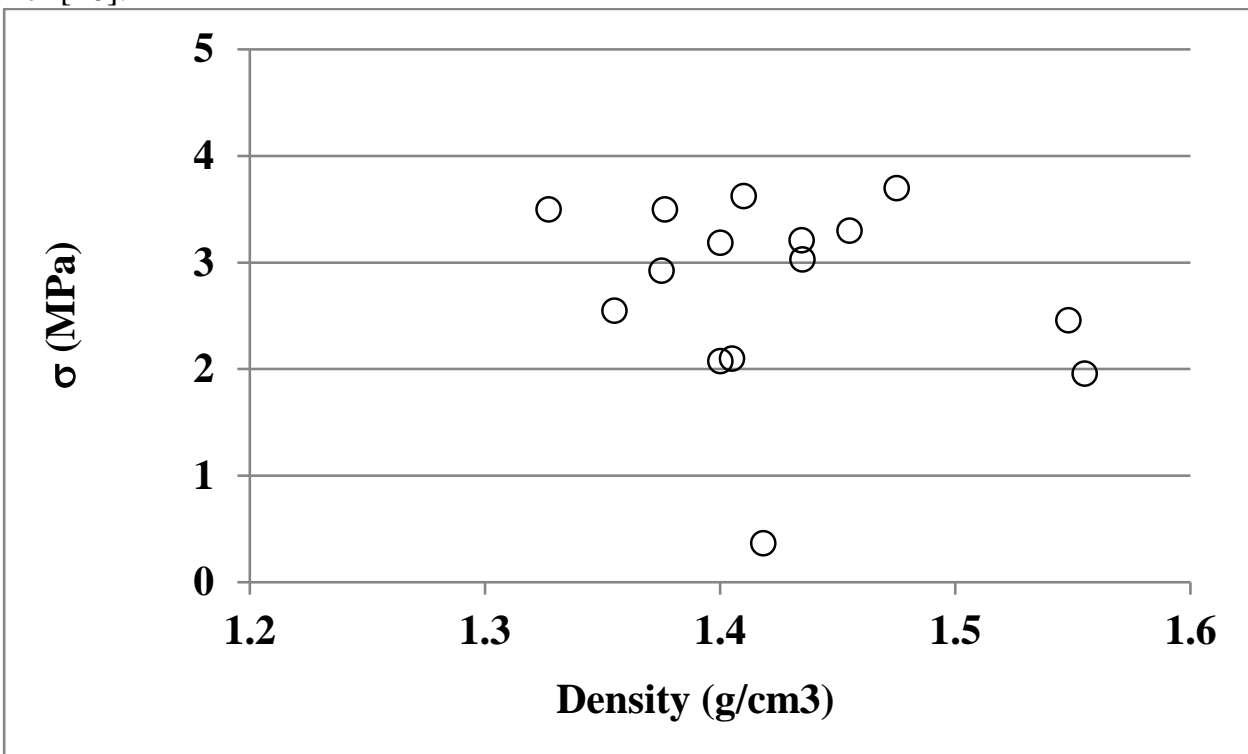

Fig. 13: Compressive strength as a function of density for mixes with lower densities.

\section{ACKNOWLEDGEMENTS}

This scientific research has been conducted at the University College of Applied Sciences (UCAS) of Gaza, Palestine, many thanks for Sham B. Elaqra for her helps.

\section{REFERENCES}

1- Y. Abu El combos, Habil, G. Busch, Solid waste management in Gaza strip problems and solution, report for Environmental Quality Authority (EQA), State of Palestine. 
2- S. Sharma, V.V. Arora and A. Kumar, Study of usage of bottom ash as part replacement of sand for making concrete blocks, publication of Centre for Construction Development and Research National Council for Cement and Building Materials, 2012.

1- M. P. Kadam and Y. D. Patil, Effect of coal bottom ash as sand replacement on the properties of concrete with different water cement ratio, International Journal of Advanced Technology in Civil Engineering, ISSN: $2231-5721$, Volume-2, Issue-1, 2013.

2- T. Subramani and C. Sumathi, Experimental Investigation Of Partial Replacement Of Cement With Fly Ash And Sand With Bottom Ash And Glass Used In Concrete, International Journal of Application or Innovation in Engineering \& Management (IJAIEM), Volume 4, Issue 5, May 2015.

3- R. Raju, M. M. Paul and K. A. Aboobacker, Strength performance of concrete using bottom ash as fine aggregate, IMPACT: International Journal of Research in Engineering and Technology (IMPACT: IJRET) ISSN(E): 2321-8843; ISSN(P): 2347-4599, Vol. 2, Issue 9, Sep 2014, 111-122.

4- P. Bhuvaneshwari and R. Murali, Strength Characteristics of Glass Fiber on Bottom Ash Based Concrete, International Journal of Science, Environment and Technology, Vol. 2, No 1, 2013, 90 - 102.

5- C. Mathiraja, Mechanical Properties of Concrete using Bottom Ash Manufacturing Sand and Metallic Fibres, International Journal of Innovations in Engineering and Technology (IJIET), Vol. 3 Issue 2 December 2013.

6- Gagandeep and K. Gupta, Bottom Ash as Partial Sand Replacement in Concrete- A Review, International Journal of Latest Research In Engineering and Computing (IJLREC), Volume 5, Issue 2 , Page No. 13-16 March-April 2017.

7- M. S. bin Mohd Sani, F. bt Muftah, Z. Muda, The Properties of Special Concrete Using Washed Bottom Ash (WBA) as Partial Sand Replacement, International Journal of Sustainable Construction Engineering \& Technology, Vol 1, No 2, December 2010.

8- A. Sachdeva and G. Khurana, Strength Evaluation of Cement Concrete Using Bottom Ash as a Partial replacement of Fine Aggregates, International Journal of Science, Engineering and Technology, 2015, Volume 3 Issue 6.

9- H. Ahmad , N. Wahid, M.F.A. Rahman and N.A. Karim, Influence of Fly Ash on the Compressive Strength of Foamed Concrete at Elevated Temperature, MATEC WEB Conference 15, 01003, 2014

10- .A. DilipKumar, B. AshishGupta and A. Ram, Uses of Bottom ash in the Replacement of fine aggregate for Making Concrete, International Journal of Current Engineering and Technology, Vol.4, No.6 (Dec 2014)).

11- A S Cadersa I Auckburally, Use of Unprocessed Coal Bottom Ash as Partial Fine Aggregate Replacement in Concrete, University of OF Mauritius Research Journal, Volume 20, 2014.

12- M. P. Kadam, Y. D. Patil, The Effect of sieved Coal Bottom Ash as a Sand Substitute on the Properties of Concrete with Percentage Variation in Cement,

13- P. Tang, Florea and Brouwers, The characterization of MSWI bottom ash, project sponsors of the Building Materials research group at TU Eindhoven, 2013.

14- I. J. BaniOdi, Utilization of Olive Husk as a Replacement of Fine Aggregate in Portland Cement Concrete Mixes for Non-Structural Uses 2007

15- V. R. Nadig, J. Sanjith, A. Ranjith and B. M. Kiran, Bottom Ash as Partial Sand Replacement in ConcreteA Review 2015.

16- H. ELAQRA, R. Rustom, Effect of Using Glass Powder as Cement Replacement on Rheological Properties of Cement Paste. Construction and Building Materials. 179 (2018) 326-335.

17- H. Cagnon, J.E. Aubert, M. Coutand, C. Magniont, Hygrothermal properties of earth bricks, Energy and Buildings, Volume 80, September 2014, Pages 208-217

18- A. Laborel-Préneron, J.E. Aubert, C. Magniont, C. Tribout, A. Bertron, Plant aggregates and fibers in earth construction materials: A review, Construction and Building Materials, Volume 111, 15 May 2016, Pages 719-734

19- ASTM D5357-03, (2013), Standard Test Method for Determination of Relative Crystallinity of Zeolite Sodium A by X-ray Diffraction, ASTM International, West Conshohocken, PA, 2013.

20- ASTM C136 / C136M-14, Standard Test Method for Sieve Analysis of Fine and Coarse Aggregates, ASTM International, West Conshohocken, PA, 2014.

21- ASTM C192 / C192M-16a, Standard Practice for Making and Curing Concrete Test Specimens in the Laboratory, ASTM International, West Conshohocken, PA, 2016, www.astm.org.

22- ASTM C642-13, Standard Test Method for Density, Absorption, and Voids in Hardened Concrete, ASTM International, West Conshohocken, PA, 2013, www.astm.org.

23- ASTM C39 / C39M-18, Standard Test Method for Compressive Strength of Cylindrical Concrete Specimens, ASTM International, West Conshohocken, PA, 2018, www.astm.org.

24- H. A. ELAQRA, Effect of the use of autoclave on the mechanical properties of the Bio-Construction Materials. accepted paper, Islamic University of Gaza.

25- H. A. Elaqra, M. J. Al-Afghany, A. B. Abo-Hasseira, I. Elmasry, A. Tabasi and M. Alwan, Effect of Immersion Time of Glass Powder in The New Mixing Method on Mechanical Properties of Concert Contain Glass Powder 
as Cement Replacement, submitted paper to construction and building materials.

26- H. A. Elaqra, M. Abou Haloub and R. Rustom, Effect of New Mixing Method of Glass Powder as Cement Replacement on Mechanical Behavior of Concrete, submitted paper to construction and building materials. 